DOI: https://doi.org/10.15407/techned2019.05.027

\title{
SYNCHRONOUS BALANCED REGULATION OF MULTIPHASE SYSTEM BASED ON MODULATED DIODE-CLAMPED INVERTERS
}

\author{
Journal \\ Publisher \\ ISSN \\ Issue
}

Pages

\author{
Tekhnichna elektrodynamika \\ Institute of Electrodynamics National Academy of Science of Ukraine \\ 1607-7970 (print), 2218-1903 (online) \\ No 5, 2019 (September/Oktober) \\ $27-35$
}

\begin{abstract}
Authors
Oleschuk V.*, Ermuratskii V.

Institute of Power Engineering of Moldova, 5 Academy Str., Kishinau, MD-2028. Moldova, e-mail: oleschukv@hotmail.com, ermuratskie@gmail.com

* ORCID ID : http://orcid.org/0000-0002-7413-4867
\end{abstract}

\begin{abstract}
Investigation of six-phase drive system on the basis of four diode-clamped inverters, regulated by the modified control and modulation algorithms providing both power balancing capability and voltage symmetries in system, has been done. System circuit consists of two groups of two inverters, supplying a six-phase open-end winding asymmetrical induction motor. Each diode-clamped inverter is connected across the open-end of two three-phase stator windings. The developed control and PWM schemes and techniques insure required power sharing ratios between four insulated dc sources due to special control correlations with such functions, as coefficients of modulation of inverters and magnitudes of voltages of dc sources. Mutual comparison of behavior of system with two basic schemes of synchronous pulsewidth modulation has been executed. Analysis of harmonic composition of basic voltages of multi-inverter system proves the fact, that for the all analyzed control modes, connected with balanced operation of drive under different conditions, voltage waveforms have symmetry for any control regimes, including control modes with fractional frequency ratios between switching frequency of inverters and fundamental frequency of system, with absence in its spectra of undesirable subharmonics (of the fundamental frequency). References 25, figures 5, tables 2.
\end{abstract}


Key words: voltage source inverter, induction motor with open-end windings, modulation strategy, voltage spectra.

Received: 29.03.2019

Accepted: 07.05.2019

Published: 01.08.2019

\section{References}

1. Bose B.K. Modern Power Electronics and AC Drives. Prentice Hall, Upper Saddle River, 2002. 724 p.

2. Kazmierkowski M.P., Krishnan R., Blaabjerg F. Control in Power Electronics: Selected Problems. Academic Press, 2002. 544 p.

3. Mohan N., Undeland T.M., Robbins W.P. Power Electronics. John Wiley \& Sons, 2003. 587

p.

4. Bose B.K. Power electronics, smart grid, and renewable energy systems. Proc. of the IEEE. 2017. Vol. 105, No 11. Pp. 2011-2018.

DOI:

https://doi.org/10.1109/JPROC.2017.2745621

5. Levi E. Advances in converter control and innovative exploitation of additional degrees of freedom for multiphase machines. IEEE Trans. Ind. Electron. 2016. Vol. 63. No 1. Pp. 433-448. DOI:

https://doi.org/10.1109/TIE.2015.2434999

6. Barrero F., Duran M. Recent advances in the design, modeling, and control of multiphase machines. Part I. IEEE Trans. Ind. Electron. 2016. Vol. 63. No 1. Pp. 449-458. DOI: https://doi. org/10.1109/TIE.2015.2447733

7. Grandi G., Tani A., Sanjeevikumar P., Ostojic D. Multi-phase multi-level AC motor drive based on four three-phase two-level inverters. Proc. of IEEE Int'l Symp. on Power Electronics, Electrical Drives,

Automation and Motion

(SPEEDAM'2010), Pisa, Italy. 2010. Pp. 1768-1775.

DOI:

https://doi.org/10.1109/SPEEDAM.2010.5545091

8. Oleschuk V., Grandi G., Sangeevikumar P. Simulation of processes in dual three-phase system on the base of four inverters with synchronized modulation. Advances in Power Electronics.

2011. Pp. 1-9.

DOI:

https://doi.org/10.1155/2011/581306

9. Grandi G., Sanjeevkumar P., Casadei D. Preliminary hardware implementation of a six-phase quad-inverter induction motor drive. Proc. of European Power Electronics Conf. (EPE'2011), 
Birmingham, United Kingdom. 2011. Pp. 1-9.

10. Oleschuk V., Prudeak R., Sizov A. Dual three-phase multiinverter system controlled by specialized algorithms of synchronized PWM: MATLAB-based steady-state analysis. Tekhnichn a Elektrodynamika

. 2014. No 1. Pp. 35-40.

11. Holtz J. Pulsewidth modulation for electronic power conversion. Proc. of the IEEE. 1994.

Vol. 82. No 11. Pp. 1194-1214.

DOI:

https://doi.org/10.1109/5.301684

12. Hava A.M., Kerkman R.J., Lipo T.A. A high-performance generalized discontinuous PWM algorithm. IEEE Trans. Ind. Appl. 1998. Vol. 34. No 8. Pp. 1059-1071. DOI: https://doi.org/10.1 $109 / 28.720446$

13. Holmes D.G., Lipo T. Pulse Width Modulation for Power Converters. Principles and Practice. IEEE Press, 2003. 628 p. DOI: https://doi.org/10.1109/9780470546284

14. Mykhalskyi V.M., Sobolev V.M., Chopyk V.V., Shapoval I.A. Self-commutated voltage inverters control with maintenance of maximum modulation coefficient by undistorted output voltage generation with the help of modified PWM. Tekhnichna Elektrodynamika. 2010. No 1. Pp. 49-59.

15. Lypkivskyi K.O., Khalikov V.A., Mozharovskyi A.H. Analysis of AC voltage parameters conversion in electrotechnical and electrotechnological systems. Tekhnichna Elektrodynamika. 2010. No 1. Pp. 30-41.

16. Mikhalsky V.M., Sobolev V.M., Chopyk V.V., Shapoval I.A. Definition of harmonic content and quality factors of voltage-source inverter output voltage with application of discontinuous modulation functions for the PWM. Tekhnichna Elektrodynamika. 2010. No 2. Pp. 41-51. 17. Oleschuk V., Sizov A., Bose B.K., Stankovic A.M. Phase-shift-based synchronous modulation of dual inverters for an open-end winding motor drive with elimination of zero sequence currents. Proc. of IEEE Power Electronics and Drive Systems Conf. (PEDS'2005), Kuala Lumpur, Malaysia. 2005. Pp. 325-330.

18. Oleschuk V., Profumo F., Griva G., Bojoi R., Stankovic A.M. Analysis and comparison of basic schemes of synchronized PWM for dual inverter-fed drives. Proc. of IEEE Int'l Symp. on Ind. Electron . (ISIE'2006), Montreal, Canada. 2006. Pp. 2455-2461.

DOI:

https://doi.org/10.1109/ISIE.2006.295958

19. Oleschuk V., Griva G. Simulation of processes in synchronized cascaded inverters for photovoltaic application. International Review of Electrical Engineering. 2009. Vol. 4. No 5. Pp. 975-982.

20. Oleschuk V., Barrero F. Standard and non-standard approaches for voltage synchronization of drive inverters with space-vector PWM: A survey. International Review of Electrical Engineering 688-707. . 2014. Vol. 9. No 4. Pp.

10.15866/iree.v9i4.1852 DOI: https://doi.org/ 
